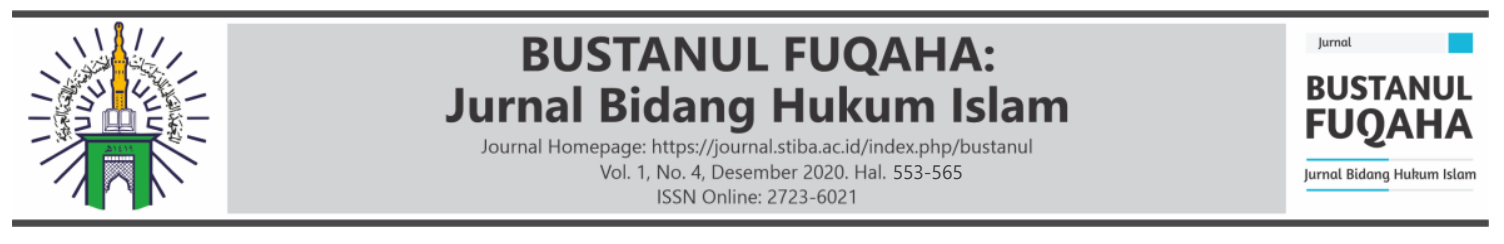

\title{
PELAKSANAAN SALAT JUMAT DI TEMPAT KERJA SELAIN MASJID DI MASA PANDEMI COVID-19 BERDASARKAN PERSPEKTIF HUKUM ISLAM
}

\author{
Ronny Mahmuddin \\ Sekolah Tinggi Ilmu Islam dan Bahasa Arab (STIBA) Makassar \\ Email: ronny.mahmuddin@stiba.ac.id \\ Fadhlan Akbar \\ Sekolah Tinggi Ilmu Islam dan Bahasa Arab (STIBA) Makassar \\ Email: fadlanakbar75@gmail.com
}

Keywords :
Covid, Legal, Friday Pray,
Mosque, Islamic Perspective

\begin{abstract}
This study aimed to describe the law of Friday prayers in offices or workplaces such as in fields, halls, mushalla, and for example in other places than mosques during the Covid-19 pandemic based on the propositions of the Koran, hadith, and fiqh principles as well as the opinions of the scholars. This type of research was a qualitative descriptive study using a literature review method in collecting data with a legal-normative approach. The results of this study indicate that the law of conducting Friday prayers in other than mosques during the Covid-19 pandemic is permissible based on the propositions of the Koran, hadith, fiqh principles, and the words of the scholars. However, if the nearest mosque can accommodate all worshipers even though they are in a tenuous prayer position during the Covid-19 pandemic, then employees are required to conduct Friday prayers at the mosque based on the opinion of most scholars, unless there is a necessity such as a remote mosque or a small mosque which cannot accommodate many worshipers or other justified age, Friday prayers are allowed at their workplace. The implementation of this research is expected to contribute theoretically and practically to religious leaders, parties with special interests, and society in general.
\end{abstract}

Kata kunci : ABSTRAK

Covid, Hukum, Salat Jumat, Masjid, Perspektif Islam

\begin{abstract}
Penulisan ini bertujuan untuk mendeskripsikan tentang hukum salat Jumat di perkantoran atau tempat kerja seperti di lapangan, aula, mushalla dan semisalnya di selain masjid pada masa pandemi Covid19 berdasarkan dalil-dalil Al-Qur'an, hadis dan kaidah fikih serta argumentatif para ulama. Jenis penulisan ini adalah penulisan deskriptif kualitatif dengan menggunakan metode telaah pustaka dalam mengumpulkan data-data dengan pendekatan hukumnormatif. Hasil dari penulisan ini menunjukkan hukum pelaksanaan salat Jumat di selain masjid pada masa pandemi Covid-19 adalah boleh berdasarkan dalil-dalil Al-Qur'an, hadis, kaidah fikih dan perkataan para ulama. Namun jika masjid terdekat dapat menampung seluruh jemaah meskipun dalam posisi saf-saf salat yang renggang pada masa pandemic Covid-19, maka para pegawai diharuskan untuk melaksanakan salat Jumat di masjid tersebut berdasarkan pendapat Jumhur Ulama, kecuali jika ada hajat seperti masjid jauh atau masjid kecil yang tidak bisa menampung banyak
\end{abstract}




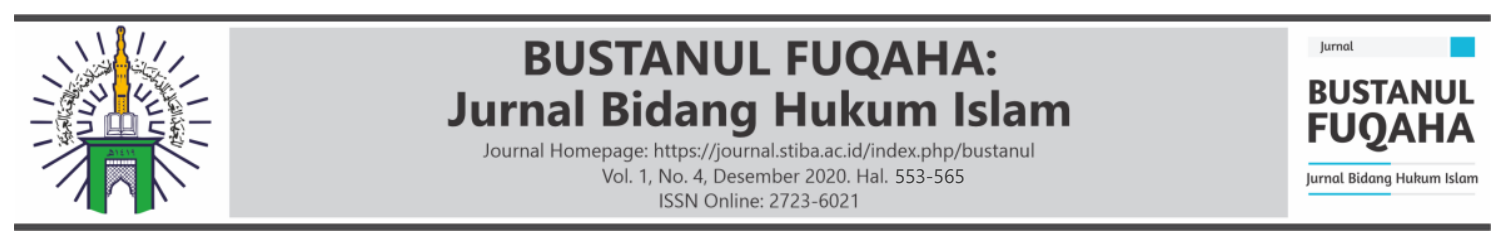

jemaah, atau uzur lain yang dibenarkan, maka diperbolehkan salat Jumat di tempat kerja mereka. Implementasi dari penulisan ini diharapkan memberikan kontribusi secara teoritis dan praktis bagi para tokoh agama, pihak yang berkepentingan secara khusus dan masyarakat secara umum.

\section{PENDAHULUAN}

Islam adalah agama yang mudah untuk dilaksanakan bagi pemeluknya, sebagaimana firman Allah swt. dalam Qs. al-Hajj/22:78, “Kami tidak menjadikan agama ini (Islam) susah bagi kalian". Begitu pula firman-Nya dalam Qs. al-Baqarah/2:185: "Allah menginginkan bagi kalian kemudahan dan tidak menginginkan bagi kalian kesusahan". Sebagaimana pula sabda Nabi saw.: "Sesungguhnya agama Islam adalah agama yang mudah". (HR. al-Bukhāri).

Aturan ini tentu memberikan pengaruh yang begitu besar terhadap pelaksanaan ibadah salat Jumat yang biasanya dihadiri banyak jemaah. Namun karena adanya aturan untuk menjaga jarak (physical distancing) sehingga saf-saf salat harus direnggangkan yang berakibat masjid tidak dapat menampung jemaah yang banyak dalam satu waktu, sehingga timbul pertanyaan, yaitu hukum pelaksanaan salat Jumat di selain masjid seperti perkantoran, musalla dan gedung-gedung atau lapangan karena kondisi Covid-19.

Kondisi penyebaran Covid-19 di Indonesia memberikan dampak kepada kehidupan beribadah kaum muslimin seperti pelaksanaan salat Jumat. Di masa new normal, pemerintah dan ulama telah mengeluarkan aturan bolehnya melaksanakan salat Jumat di masjid di daerah atau wilayah yang kondisi penyebaran virusnya terkendali dengan syarat jaga jarak saf salat (physical distancing) satu meter untuk memutus mata rantai penyebaran Covid-19. Aturan pemerintah dan ulama ini berdasar pada arahan dari para ahli medis, karena mereka yang lebih mengetahui tentang masalah wabah atau virus ini, sebagaimana firman Allah dalam Qs. al-Naḥl/16:43,

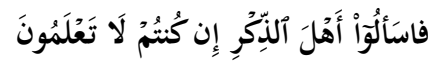

Terjemahnya:

"Maka bertanyalah kepada orang yang mempunyai pengetahuan jika kamu tidak mengetahui."

Regulasi ini tentu memberikan pengaruh yang signifikan terhadap pelaksanaan ibadah salat Jumat yang biasanya dihadiri banyak jemaah. Namun, karena adanya aturan untuk menjaga jarak (physical distancing) sehingga saf-saf salat harus direnggangkan yang berakibat masjid tidak dapat menampung jemaah yang banyak dalam satu waktu, sehingga timbul pertanyaan, yaitu hukum pelaksanaan salat Jumat di aula, musala, 


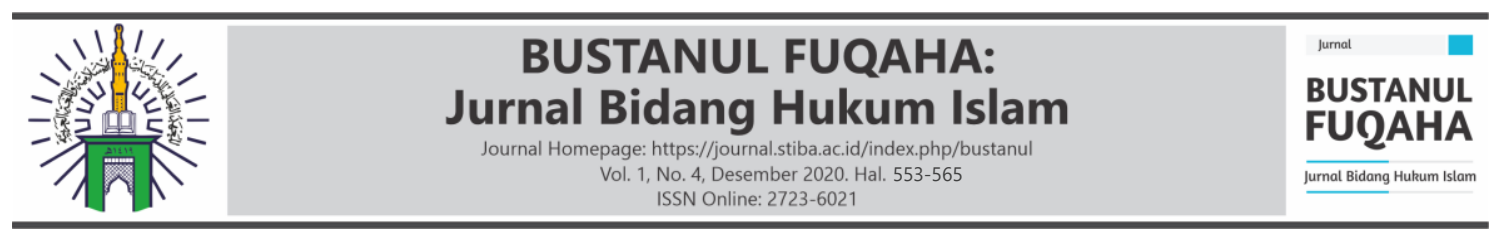

lapangan tempat kerja atau perkantoran di selain masjid karena kondisi penyebaran Covid-19.

Rumusan masalah yang dikaji pada penulisan ini, yaitu bagaimana hukum pelaksanaan salat Jumat di tempat kerja (perkantoran) selain masjid pada masa pandemi Covid-19 perspektif hukum Islam?.

Penulisan ini bertujuan untuk mendeskripsikan tentang hukum pelaksanaan salat Jumat di tempat kerja atau perkantoran selain masjid pada masa pandemi Covid-19 berdasarkan dalil-dalil Al-Qur'an, hadis dan kaidah fikih serta argumentatif para ulama.

Metode penulisan ini adalah menggunakan metode kepustakaan, yaitu menelusuri literatur-literatur primer dan sekunder yang berkaitan dengan penulisan yang dibahas. Jenis penulisan kajian ini adalah penulisan deskriptif kualitatif dengan menggunakan pendekatan hukum/normatif, yaitu mendeskripsikan dalil-dalil syar' $i$, kaidah-kaidah fikih dan pendapat para ulama tentang hukum pelaksanaan salat Jumat di selain masjid pada masa pandemi Covid-19.

Penulisan-penulisan yang relevan dengan kajian ini di antaranya adalah kajian yang diteliti oleh Eko Misbahuddin dan Muhammad Yusram dalam artikel jurnal yang berjudul, "Hukum Salat Berjemaah di Masjid dengan Saf Terpisah Karena Wabah". Tujuan dari penulisan ini adalah mendeskripsikan hukum salat berjemaah dengan saf terpisah pada masa pandemi Covid-19. Hasil penulisan ini menunjukkan bahwa hukum salat berjemaah dengan saf renggang karena wabah adalah sah, namun mengikuti arahan pemerintah dan ulama (MUI) untuk salat di rumah adalah lebih diutamakan pada saat pandemi ${ }^{1}$.

Penulisan yang juga relevan dengan penulisan ini, adalah artikel jurnal yang ditulis oleh Ronny Mahmuddin dengan judul, “Hukum Pelaksanaan Salat Jumat Dua Gelombang di Satu Masjid di Masa Pandemi Covid-19". Penulisan ini bertujuan untuk mendeskripsikan hukum pelaksanaan salat Jumat dua gelombang di satu masjid di masa pandemi Covid-19. Hasil penulisan menunjukkan dibolehkannya pelaksanaan salat Jumat dua gelombang di satu masjid di masa pandemi Covid-19 karena ada hajat yang mendesak/darurat untuk mencegah penyebaran virus ${ }^{2}$.

Penulisan lain yang relevan dengan penulisan ini, adalah artikel jurnal yang berjudul, "Darurat Moderasi Beragama di Tengah Pandemi Corona Virus Desease 2019 (Covid-19)" yang ditulis oleh Abdul Syatar, Muhammad Majdi Amiruddin dan Arif

${ }^{1}$ Lihat: Eko Misbahuddin Hasibuan dan Muhammad Yusram. (2020). "Hukum Salat Berjemaah di Masjid dengan Saf Terpisah Karena Wabah". BUSTANUL FUQAHA: Jurnal Bidang Hukum Islam, Vol.1 No.2, h.106-124.

${ }^{2}$ Lihat: Ronny Mahmuddin, Fadlan Akbar dan Iskandar. (2020). "Hukum Pelaksanaan Salat Jumat Dua Gelombang di Satu Masjid di Masa Pandemi Covid-19". BUSTANUL FUQAHA: Jurnal Bidang Hukum Islam, Vol.1 No.3, h. 350-365. 


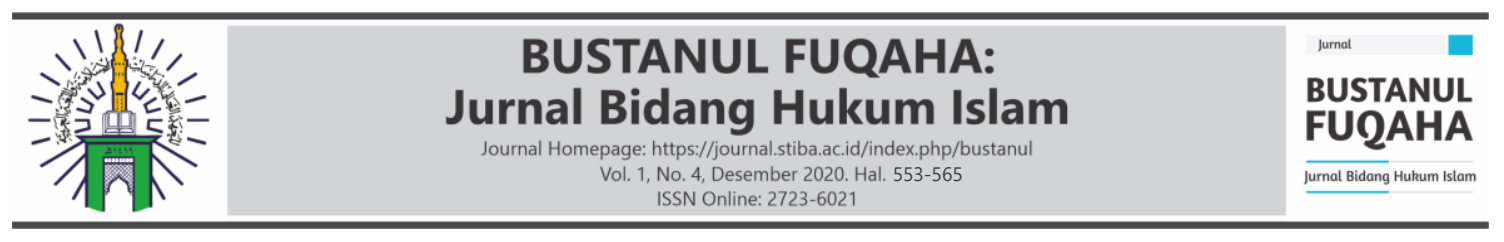

Rahman. Tujuan penulisan ini adalah untuk mendeskripsikan pentingnya menjaga moderasi beragama/beribadah di masa pandemi. Hasil dari penulisan ini menunjukkan bahwa prioritas moderat dalam beragama/beribadah di masa pendemi covid-19 menjadi suatu keharusan ${ }^{3}$.

Penelitian yang digarap oleh Muh. Hamdan Fathur Rahim yang berjudul "Persepsi Tokoh Agama Tentang Shalat Jumat Di Dua Masjid Yang Berdekatan (Studi Kasus Desa Gilang Kec.Ngunut Kab.Tulungagung)" Tujuan dari kajian ini adalah untuk mengetahui persepsi tokoh agama tentang hukum salat Jumat di dua masjid yang berdekatan di desa Gilang-Tulungagung, dan untuk mendeskripsikan persepsi para ulama fikih tentang hukum salat Jumat di dua masjid yang berdekatan. Hasil dari penulisan ini menunjukkan, bahwa: (1) Persepsi tokoh masyarakat desa gilang tentang mendirikan salat Jumat di dua masjid yang berdekatan, adalah dibolehkan dalam syariat, dan salat Jumat di dua masjid tersebut dianggap sah, karena adanya hajat mendesak yakni antara kedua belah pihak tidak dapat dikumpulkan atau dipersatukan untuk mendirikan satu salat Jumat di dalam satu masjid; (2) Pendapat mayoritas ulama mengatakan bahwa pada dasarnya mendirikan salat Jumat di dua masjid yang berdekatan dalam satu desa secara bersamaan ( Ta'addud al-Jumu'ah) hukumnya tidak diperbolehkan, apabila tidak ada uzur apapun yang menghalangi untuk dikerjakan dalam satu tempat (desa/kota) ${ }^{4}$.

Yang membedakan penulisan-penulisan di atas dan penulisan lainnya dengan kajian penulis adalah, bahwa belum ada satu pun penulisan yang mengupas tentang hukum salat Jumat di selain masjid pada masa pandemi Covid-19. Oleh karena itu, penulis memandang bahwa kajian ini adalah kajian yang bernilai novelty (kebaruan) dan layak untuk diteliti lebih dalam.

\section{PEMBAHASAN}

\section{Hukum Pelaksanaan Salat Jumat di Selain Masjid Pada Masa Pandemi Covid-19}

Hukum pelaksanaan salat Jumat di selain masjid seperti di tempat-tempat kerja, perkantoran, lapangan atau aula (tempat terbuka) secara umum dibolehkan, apatah lagi jika ada hajat mendesak atau darurat. Tidak ada syarat sahnya salat Jumat harus dilaksanakan di masjid. Yang dipersyaratkan sahnya pelaksanaan salat Jumat adalah dilakukan di desa, perkotaan atau pinggiran perkotaan yang ada pemukiman penduduknya.

${ }^{3}$ Lihat: Abdul Syatar, dkk, (2020). "Darurat Moderasi Beragama di Tengah Pandemi Virus Corona 2019 (Covid-19)”. Kuriositas: Media Sosial dan Keagamaan. Vol. 13 No.1, h. 1-13.

${ }^{4}$ Lihat: Muh. Hamdan Fathur Rahim, "Persepsi Tokoh Agama Tentang Shalat Jumat Di Dua Masjid Yang Berdekatan (Studi Kasus Desa Gilang Kec.Ngunut Kab.Tulungagung)", Skripsi (Tulungagung: Jurusan Hukum Keluarga Islam, IAIN Tulungagung, 2019), h. 51-68. 


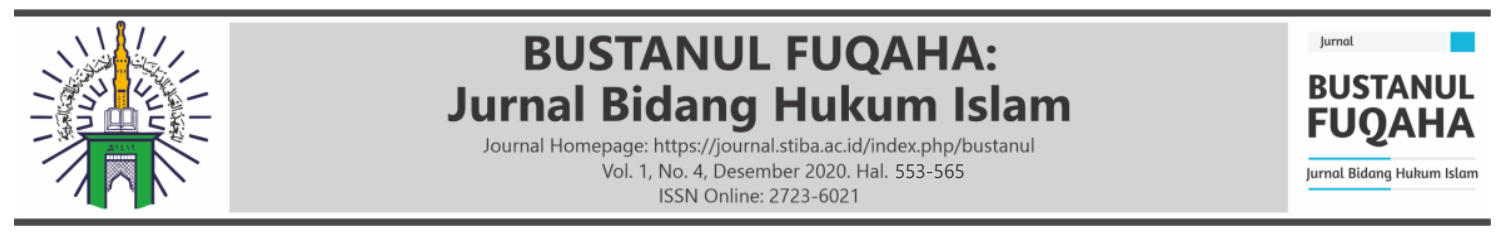

'Abd. al-Raḥmān al-Sa'diy dalam kitab Ibhāj al-Mu'minīn oleh 'Abdullah ibn 'Abd. al-Raḥmān al-Jibrīn menyebutkan syarat sahnya salat Jumat ada lima. Kelima syarat itu adalah penduduk setempat, dilaksanakan pada waktunya di waktu Zuhur hingga sebelum masuk waktu Asar, dilaksanakan di desa/kota, didahului dengan dua khutbah, dan orang yang melaksakannya adalah orang merdeka bukan budak ${ }^{5}$. Pernyataan al-Sa 'diy di atas menunjukkan bahwa salat Jumat tidah diharuskan dilaksanakan di masjid, karena tidak termasuk dalam syarat sahnya salat Jumat.

Jika para pegawai melaksanakan salat Jumat di masjid terdekat dari tempat kerja mereka, maka itu yang lebih utama. Jumhur ulama membolehkan pelaksanaan salat Jumat di berbagai tempat di satu kampung atau kota jika ada hajat mendesak, seperti letak masjid yang sangat jauh atau kondisi masjid kecil yang tidak bisa menampung banyak jemaah. Terlebih lagi pada kondisi Covid-19 sekarang ini yang terjadi di Indonesia, maka pelaksanaan salat Jumat di selain masjid seperti di perkantoran atau semisalnya diperbolehkan, karena kondisi darurat atau hajat yang mendesak. Diupayakan para pegawai melaksanakan salat Jumat di masjid terdekat dari tempat kerja jika memungkinkan, namun jika tidak memungkinkan karena masjid tidak bisa menampung jemaah yang banyak akibat dari posisi saf-saf salat yang direnggangkan, maka diperbolehkan bagi para pegawai atau pekerja melaksanakan salat Jumat di tempat kerja mereka.

Di bawah ini, penulis memaparkan dalil-dalil syar' $i$, kaidah-kaidah fikih dan argumentatif para ulama tentang bolehnya pelaksanaan salat Jumat di tempat kerja (perkantoran), gedung atau lapangan (aula) selain masjid karena kondisi darurat atau hajat mendesak, seperti pada masa pandemi Covid-19, sebagai berikut:

\section{Argumentatif Dalil-Dalil Al-Qur'an:}

1. Firman Allah swt dalam Qs. al-Baqarah/2:185,

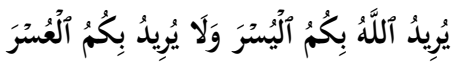

Terjemahnya:

"Allah menghendaki kemudahan bagimu, dan tidak menghendaki kesukaran bagimu."

2. Firman Allah swt. dalam Qs. al-Māidah/5:6,

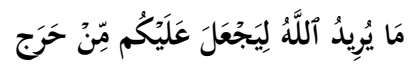

Terjemahnya:

"Allah tidak hendak menyulitkan kamu."

${ }^{5}$ Lihat: 'Abdullāh ibn 'Abd al-Raḥmān al-Jibrīn, Ibhāj al-Mu'mininn bi Syarhi Manhaj al-Sālikīn wa Taựihh al-Fiqhi fi al-Dīn (Cet. I; Riyad: Dār al-Watan, 1422), h. 217-218, dan Ṣālị̣ ibn Fauzān al-Fauzān, al-Mulakhkhas al-Fiqhiy (Cet. I; Riyad: Dār al-‘Āsimah, 1423), h. 259-260. 


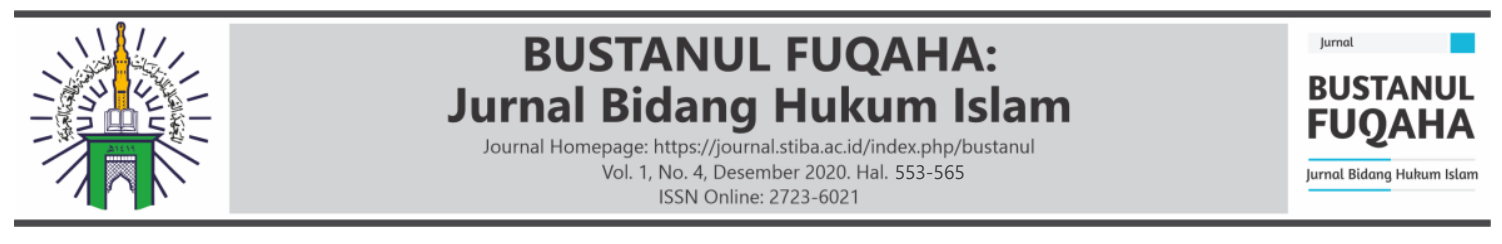

3. Firman Allah dalam Qs. al-Hajj/22:78,

$$
\text { وَمَا جَعَلَ عَلَيَكُمُ فِي الْلِّينِ مِنْ حَرج }
$$

Terjemahnya:

"Dia (Allah) sekali-kali tidak menjadikan untuk kamu dalam agama suatu kesempitan."

Ayat-ayat di atas sangat jelas menunjukkan bahwa Allah menurunkan syariat Islam penuh dengan kemudahan dan tidak menyusahkan hamba-hamba-Nya, karena tujuan syariat adalah untuk kemaslahatan manusia di dunia dan di akhirat ${ }^{6}$, bahkan sesuatu yang diharamkan tatkala dalam kondisi darurat maka sesuatu yang diharamkan itu menjadi halal atau memilih yang jauh lebih ringan mudaratnya. Seperti halnya hasil penelitian oleh Idris, dkk., yang menganalisis penerapan kaidah Laa Darar walaa Dirar dalam dunia medis dan kedokteran, yakni mengambil mudarat yang lebih ringan dan menghindari mudarat yang lebih besar. ${ }^{7}$ Oleh karena itu, pelaksanaan salat Jumat di selain masjid, seperti di gedung, aula, musala dan lapangan adalah diperbolehkan jika darurat atau ada hajat yang mendesak berdasar pada ayat-ayat di atas.

\section{Argumentatif Dali1 -Dalil Hadis.}

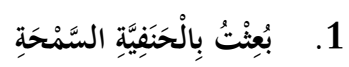

Artinya:

"Saya diutus dengan membawa ajaran tauhid yang mudah".

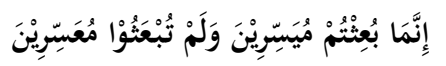

Artinya:

"Sesungguhnya kalian diutus untuk memberikan kemudahan dan kalian tidak diutus untuk memberikan kesusahan kepada orang lain"9.

Hadis-hadis di atas menunjukkan bahwa Islam yang dibawa oleh Rasulullah saw. adalah agama yang mudah dan tidak menyusahkan umatnya, apatah lagi jika ada hal-hal yang sifatnya darurat yang menyusahkan, maka Islam telah memberikan solusi. Sebagaimana dalam ibadah puasa, Rafi mengatakan bahwa golongan yang mendapatkan rukhsah (keringanan) adalah orang sakit, musafir, wanita haid atau nifas, wanita hamil

\footnotetext{
${ }^{6}$ Usman, M. H., Aswar, A., \& Irawan, A. W., "Syariat Islam dan Kemaslahatan Manusia di Era New Normal pada Kegiataan Keagamaan dan Pendidikan”, FENOMENA 12 no. 1 (2020): h. 90.

${ }^{7}$ Idris, M. N., \& Anita, K., “Analisis Implementasi Kaidah Fikih Lā Ḍarar Wa Lā Dirār dalam Kedokteran Modern pada Kasus Tindakan Operasi”, NUKHBATUL'ULUM: Jurnal Bidang Kajian Islam,6 no. 1 (2020); h. 50.

${ }^{8}$ Al-Imām Aḥmad ibn Hanbal, Musnad al-Imām Aḥmad ibn Hanbal, Vol. XXXVI (Cet. I; T.t: Muassasah al-Risālah, 1421), h. 624.

${ }^{9}$ Muhammad ibn Ismā'īl al-Bukhāriy, Sahīh al-Bukhāriy, Vol. I (Dar Tuq al-Najah, 1422), h. 54.
} 


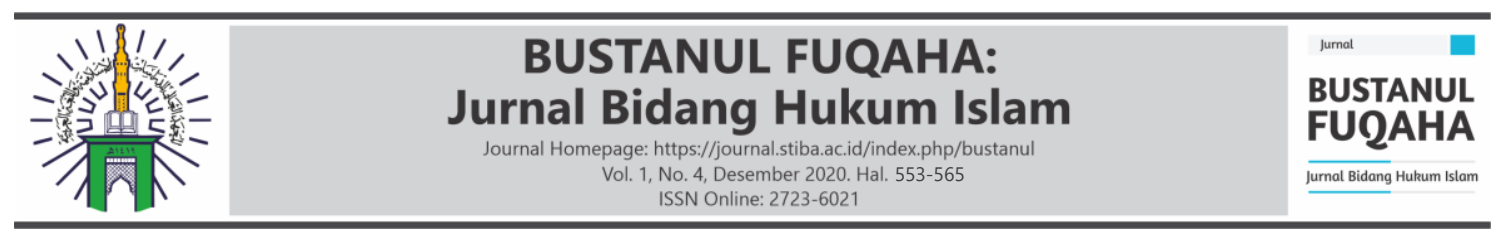

atau menyusui, dan orang tua renta ${ }^{10}$. Demikian pula dalam pelaksanaan salat Jumat di selain masjid karena darurat atau hajat mendesak, maka hukumnya boleh karena sejalan dengan hadis-hadis di atas.

\section{Argumentatif Kaidah-Kaidah Fikih:}

\section{Kaidah Fikih: al-Masyaqqah Tajlibu al-Taisïr}

Kaidah ini menunjukkan bahwa, tatkala seseorang menemukan kesusahan maka kesusahan itu menjadi sebab kemudahan ${ }^{11}$, seperti seseorang yang sakit yang tidak bisa terkena air, maka dibolehkan baginya untuk tidak berwudu dan diganti dengan tayamum. Oleh karena itu, perlunya perenggangan saf salat meskipun berdampak pada pelaksanaan salat Jumat di tempat-tempat selain masjid untuk mencegah penyebaran Covid-19.

\section{Kaidah Fikih: Dar'u al-Mafāsid Muqaddam 'alā Jalbi al-Masāāị}

Dari kaidah ini menunjukkan bahwa mencegah kemudaratan lebih didahulukan daripada mendapatkan kemaslahatan ${ }^{12}$. Oleh kerena besarnya mudarat yang ditimbulkan jika salat Jumat dilaksanakan dalam keadaan saf-saf yang rapat, maka kemudaratan ini harus dicegah dengan merenggangkan saf. Oleh karena itu, dibolehkan pelaksanaan salat Jumat di selain masjid karena darurat atau hajat yang mendesak berdasar pada kaidah "Dar'u al-Mafásid Muqaddam 'alā Jalbi al-Mașālih".

\section{Kaidah Fikih: al-Maisūr Là Yasqut bi al-Ma'sūr}

Kaidah ini menunjukkan bahwa sesuatu yang masih bisa dikerjakan oleh seseorang, maka tidak boleh ditinggalkan hanya karena ada kesusahan ${ }^{13}$. Berkaitan dengan pelaksanaan salat Jumat di saat pandemi Covid-19, maka salat Jumat tidak dibolehkan untuk ditinggalkan selama salat tersebut bisa dikerjakan sesuai kemampuan seseorang, yaitu salat dalam keadaan saf direnggangkan yang berakibat dilaksanakannya salat Jumat di selain masjid, karena kondisi masjid yang tidak bisa menampung seluruh jemaah dalam satu waktu, kecuali jika pemerintah dan ulama mengeluarkan aturan untuk menutup masjid sementara waktu melihat kondisi Covid-19 yang tidak terkendali, maka pada saat itu tidak diperkenankan menyelisihi aturan pemerintah dan ulama demi menjaga persatuan dan kesatuan kaum muslimin, sebagaimana kaidah fikih"14 berbunyi: "Hukmu

\footnotetext{
${ }^{10}$ Rafi, I., "Golongan yang Mendapatkan Rukhșah dalam Ibadah Puasa dan Konsekuensi Hukumnya”, NUKHBATUL'ULUM: Jurnal Bidang Kajian Islam 4 no. 2 (2018): h. 218.

${ }^{11}$ Lihat: Muhammad Sidqiy ibn Ā̆mad al-Burnū, al-Wajīz fi I⿳亠̄ăh al-Qawāid al-Fiqhiyyah alKulliyyah, h. 218 dan 'Abdullah ibn Salih al-Fauzan, Syarhu Jam'u al-Maḥsūl fi Syarhi Risālah ibn Sa'diy fi al-Ușül(Cet. I; Riyad: Dar al-Muslim, 1424), h. 105.

${ }^{12}$ Lihat: Muḥammad Șidqiy ibn Ā̆mad al-Burnū, al-Wajīz fi I⿳̣̄ah al-Qawāid al-Fiqhiyyah alKulliyyah, h. 265.

${ }^{13}$ Lihat: Muḥammad Ṣidqiy ibn Ah̆mad al-Burnū, al-Wajīz fi I⿳̣̂h al-Qawāid al-Fiqhiyyah alKulliyyah, h. 396.

${ }^{14}$ Lihat: Abū al-Abbā̄ Syihābuddin Aḥmad ibn Idrìs al-Maliki al-Qarāi, Anwār al-Burūq fí Anwā'i al Furūq, Vol. II (Kuwait: Dār al-Nawādir, 1431), h. 103.
} 


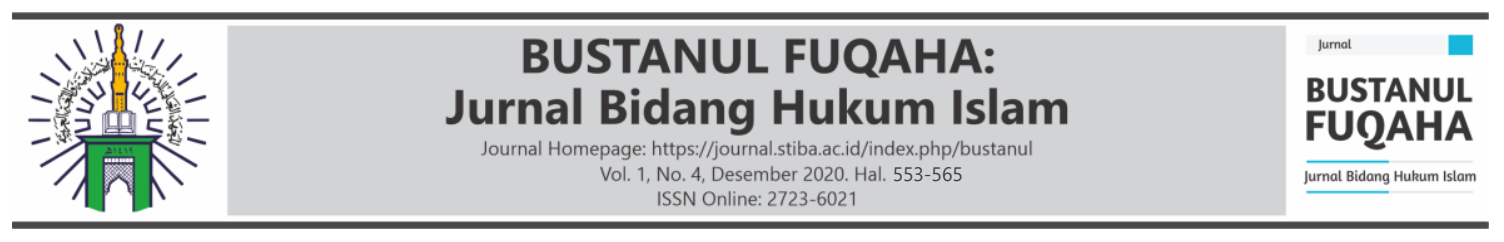

al-Hākim fi Masāil al-Ijtihād Yarfa' $u$ al-Khiläf' artinya "Keputusan hakim (pemerintah) menyelesaikan perbedaan pendapat di tengah umat".

Salat Jumat dalam kondisi tersebut harus tetap dikerjakan meskipun ada kesusahan yang dihadapi, yakni kondisi covid meskipun salat Jumat harus dilaksanakan di selain masjid. Oleh karena itu, pelaksanaan salat Jumat di selain masjid -pada wilayah yang penyebaran covidnya terkendali sebagaimana arahan pemerintah dan ulama- selama bisa dilaksanakan karena darurat atau hajat yang mendesak, maka hukumnya boleh berdasarkan kaidah fikih "al-Maisūr Là Yasqut bi al-Ma'sūr. Berdasarkan kaidah ini, seorang muslim tidak diperbolehkan meninggalkan salat Jumat selama masih ada kemudahan untuk melaksanakannya meskipun ada sedikit kendala/kesusahan, yaitu salat Jumat di selain masjid.

\section{Kaidah Fikih: İāa Dāqa al-Amru Ittasa'}

Kaidah ini menunjukkan bahwa apabila seseorang menemukan kesulitan karena suatu sebab darurat, maka diberikan kemudahan baginya untuk melakukan sesuatu yang diharamkan ${ }^{15}$. Berkaitan dengan pelaksanaan salat Jumatdi selain masjid karena darurat atau kebutuhan yang mendesak, maka diperbolehkan. Oleh karena itu, pelaksanaan salat Jumat di selain masjid karena darurat atau hajat yang mendesak diperbolehkan berdasarkan kaidah fikih: Iż̄ Dăqa al-Amru Ittasa' (Apabila suatu urusan itu sempit karena darurat, maka urusan tersebut menjadi luas $)^{16}$.

\section{Kaidah Fikih: al-Hājah Tunazzal Manzilah al-Darūrāt 'Āmmah Kānat aw Khāsșah}

Kaidah ini menunjukkan bahwa hajat (kebutuhan) dapat disamakan dengan sesuatu yang darurat baik secara umum atau khusus ${ }^{17}$. Berkaitan dengan pelaksanaan salat Jumat di selain masjid karena kebutuhan mendesak, yakni untuk menghindari kerumunan jemaah tanpa adanya jarak fisik demi menghindari cepatnya penyebaran virus corona, maka kondisi tersebut dianggap sama dengan kondisi darurat sehingga hukumnya sama dengan hukum darurat, yaitu dibolehkan sesuatu yang diharamkan karena kondisi darurat. Oleh karena itu, pelaksanaan salat Jumat di selain masjid karena hajat mendesak, maka dibolehkan berdasarkan kaidah fikih "al-Hājah Tunazzal Manzilah al-Darürät 'Āmmah Kānat aw Khāșsah".

\section{Argumentasi Para Ulama:}

Hukum pelaksanaan salat Jumat di selain masjid seperti lapangan, aula, musala dan selainnya pada masa pandemi Covid-19 relevan dengan argumentatif para ulama yang

\footnotetext{
${ }^{15}$ Lihat: Muhammad Ṣidqiy ibn Ahmad al-Burnū, al-Wajīz fi Iḍ̂̄h al-Qawāid al-Fiqhiyyah alKulliyyah, h. 230.

${ }^{16}$ Lihat: 'Abd al-Wahāb ibn Taqiyuddin al-Subkiy, al-Asybah wa al-Nazāir, Vol. 1 (Cet.I; Bairut: Dar al-Kutub al-'Ilmiyyah, 1411), h. 48 dan 'Abd al-Raḥmān ibn Abū Bakr a-Suyuṭiy, al-Asybah wa alNazāir fī Qawāid wa Furū' al-Syāfi'iyyah (Cet. I; Bairūt: Dār al-Kutub al-'Ilmiyyah, 1403), h. 83.

${ }^{17}$ Lihat: Muhammad Sidqiy ibn Ahmad al-Burnu, al-Wajīz fì I⿳̣̂̄h al-Qawāid al-Fiqhiyyah alKulliyyah, h. 242.
} 


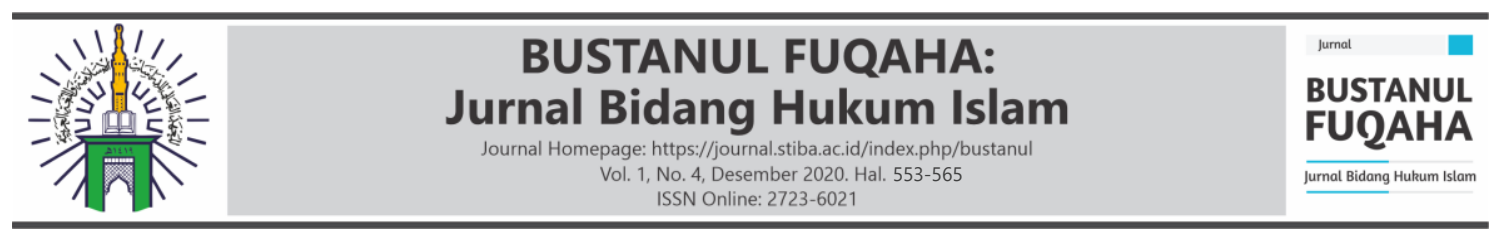

membolehkan hukum pelaksanaan salat Jumat di berbagai tempat di sebuah kota atau desa karena hajat. Di bawah ini, penulis memaparkan argumentatif para ulama tentang bolehnya salat Jumat di berbagai tempat di sebuah kota/desa karena hajat.

Pelaksanan salat Jumat di berbagai tempat selain masjid karena ada hajat mendesak diperbolehkan berdasarkan kias, yaitu dikiyaskan/disamakan dengan bolehnya salat Jumat dilaksanakan di berbagai tempat di satu daerah atau kota. Ulama Kuwait dalam situs $W W W . i s l a m w e b . n e t$ menyebutkan, bahwa jumhur ulama membolehkan pelaksanaan salat Jumat di beberapa tempat jika jarak masjid jauh, atau masjid sempit, atau takut terhadap gangguan atau uzur lainnya.

Ibn Bāz menyebutkan satu riwayat bahwa 'Ali bin Abi Tālib pada masa kekhalifaannya pernah ditanya, bahwa di kota Kufah ada orang-orang lemah yang susah bagi mereka untuk keluar melaksankan salat Id berjemaah di Sahara (padang pasir), maka beliau memerintahkan seseorang menjadi imam untuk dilaksankan salat Id di dalam kota bersama orang-orang yang lemah. Adapun 'Ali bin Abi Ṭālib melaksanakan salat Id bersama kaum musliminin di padang pasir.

Jika pelaksanaan salat Id dibolehkan di dua tempat pada zaman 'Ali bin Abi Tạalib karena ada hajat mendesak, maka pelaksanaan salat Jumat di dua tempat di satu kota atau daerah sama kondisinya dengan dibolehkannya salat Id di dua tempat, karena adanya kesulitan, hajat yang mendesak dan untuk memberikan kemudahan bagi kaum muslimin. Jumhur ulama membolehkan pelaksanaan salat Jumat di beberapa tempat karena adanya hajat yang mendesak ${ }^{18}$.

Ibn Qudāmah dalam al-Mugniy mengatakan, bahwa salat Jumat disyariatkan untuk berkumpul dan mendengar khutbah, maka dibolehkan untuk dilaksanakan di beberapa tempat jika dibutuhkan seperti pelaksanaan salat Id. Telah sahih adanya riwayat bahwa 'Ali bin Abi Ṭālib pada masa khilafah beliau melaksanakan salat Id di padang pasir (Sahara) dan meminta Abu Mas 'ūd al-Badriy untuk menjadi imam salat Ied bagi kaum muslimin yang lemah yang tidak sanggup mendatangi tempat salat Id di padang sahara. Adapun nabi Muhammad saw. tidak melaksanakan salat Jumat dua kali di satu masjid, karena para sahabat ingin sekali melaksanakan salat Jumat bersama nabi dan ingin mendengar nasehat-nasehat beliau, karena beliau adalah rasul Allah yang bertugas menyampaikan risalah dan hukum Allah, meskipun rumah-rumah mereka jauh dari masjid nabi. Adapun jika tidak ada hajat mendesak, maka tidak diperbolehkan salat Jumat dilaksanakan di berbagai tempat. Jumhur ulama mengatakan bahwa nabi dan para sahabatnya tidak pernah diriwayatkan, bahwa mereka melaksanakan salat Jumat di dua tempat atau lebih, karena pada saat itu belum ada hajat yang mendesak ${ }^{19}$.

\footnotetext{
18،Abd al-'Azīiz ibn Bāz, Majmū' Fatāwā wa Maqālāt Mutanawwi'ah (Cet. II; Riyad: Dār al-Ișda, 1421), h. 351-355.

${ }^{19}$ Muaffaquddin 'Abdullāh ibn Aḥmad ibn Qudāmah al-Maqdisiy, al-Mugniy, Vol. II (t.c; Mesir: Maktabah Qāhirah, 1388), h. 248.
} 


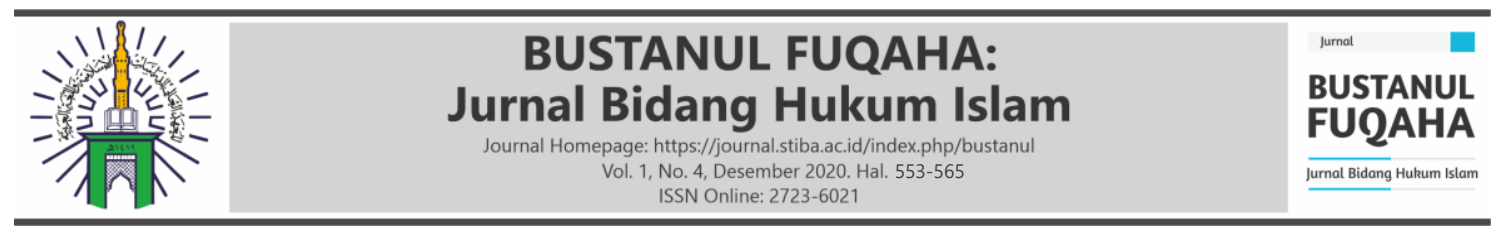

Ulama Kuwait dalam situs WWW.islamweb.net mengeluarkan fatwa, bahwa dibolehkan bagi pekerja di sebuah perusahaan melaksanakan salat Jumat di musalla tempat kerja mereka apabila mereka tidak dapat melaksanakannya di masjid, karena masjid jauh dari tempat kerja mereka yang membutuhkan waktu sekitar setengah jam berjalan kaki. Jumhur ulama membolehkan pelaksanaan salat Jumat di beberapa tempat jika jarak masjid jauh atau masjid sempit atau takut terhadap gangguan atau uzur lainnya. Tidak dipersyaratkan sahnya pelaksanaan salat Jumat harus dilaksanakan di masjid. Akan tetapi yang dipersyaratkan harus dilaksanakan di perkotaan, atau di pinggiran perkotaan atau di pedesaan. Bahkan sebagian ulama membolehkan pelaksanaan salat Jumat dilaksanakan di Padang Sahara apabila dekat dari pemukiman penduduk ${ }^{20}$.

Begitu pun disebutkan dalam situs $W W W$.islamway.net, bahwa tidak mengapa bagi pekerja atau pegawai di sebuah perusahaan melaksanakan salat Jumat di tempat kerja mereka jika pihak perusahaan melarang mereka untuk keluar dari tempat kerja mereka, dan tempat kerja mereka berada di dalam perkotaan atau di desa, karena salat Jumat boleh dilaksanakan di semua tempat selama berada di perkotaan atau di desa ${ }^{21}$.

Fatwa al-Lajnah al-Däimah mengeluarkan fatwa, bahwa kaum muslimin yang berada di luar negeri yang tidak dapat melaksanakan salat Jumat di satu masjid, karena masjid tersebut tidak bisa menampung semua jemaah, maka tidak mengapa sebagian mereka mencari tempat meskipun bukan masjid seperti tempat-tempat khusus, seperti taman-taman atau lapangan-lapangan umum yang mendapatkan izin dari pemerintah setempat untuk dijadikan tempat pelaksanaan salat Jumat ${ }^{22}$. Dalam situs islamweb.net disebutkan bahwa Imam al-Nawawi berkata: "Boleh dilaksanakan salat Jumat di beberapa tempat di semua kota yang banyak jumlah penduduknya dan sukar bagi mereka untuk berkumpul di satu tempat. Ini adalah pendapat yang benar. Al-Imām al-Mawardiy mengatakan bahwa ini adalah pendapat yang dipilih oleh al-Muzaniy, dalilnya adalah firman Allah dalam Qs. al-Hajj/22:78, “Allah tidak menjadikan atas kalian kesusahan dalam agama ini' ${ }^{23}$.

Dalam riwayat 'Abd. al-Razzāq disebutkan bahwa Ibn Jurāij mengatakan: "Saya pernah bertanya kepada 'Ațā' (seorang tabiin): "Bagaimana pendapat anda masjid Jamik (masjid raya) di Basrah tidak bisa menampung semua penduduk Basrah, apa yang mesti mereka lakukan?" 'Ațā' menjawab: "Setiap kaum yang memiliki masjid, mereka boleh melaksanakan salat Jum'at di masing-masing masjid mereka”.

\footnotetext{
${ }^{20}$ Lihat: www.islamwweb.net (diakses 15 Oktober 2020)

${ }^{21}$ Lihat: www.islamway.net (diakses 15 Oktober 2020)

${ }^{22}$ Lihat: www.islamqa.info (diakses 15 Oktober 2020)

${ }^{23}$ Lihat: www.islamweb.net (diakses 15 Oktober 2020)
} 


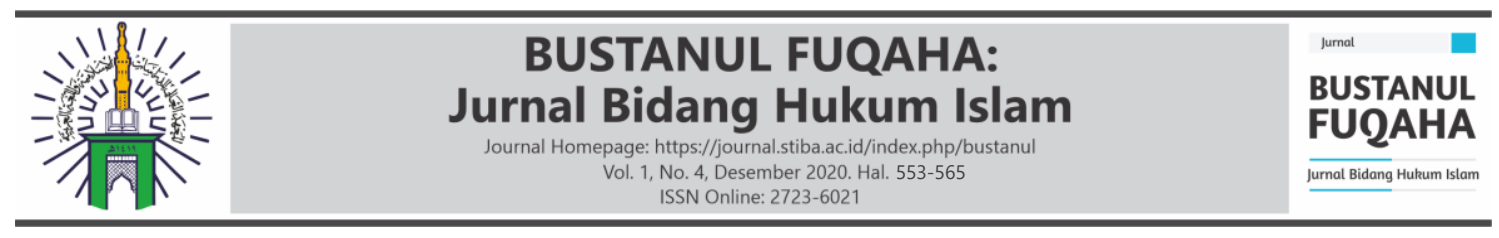

Dalam Rad al-Muhtār, Ibn 'Ābidin (ulama Hanafiyah) berkata: "Salat Jumat boleh dilaksanakan di beberapa tempat di satu kota tanpa syarat". Disebutkan dalam kitab alInșâf: "Tidak boleh dilaksanakan salat Jumat lebih dari satu tempat jika tidaka ada hajat". Mazhab Malikiyah, Syafiiyah dan Hanabilah, dan riwayat Hanafiyah yang kuat, bahwa tidak boleh dilaksanakan salat Jumat lebih dari satu tempat jika tidak ada hajat/kebutuhan.

Komite Fatwa Ulama Besar Saudi Arabia mengeluarkan fatwa, bahwa pelaksanaan salat Jumat dua kali di satu masjid tidak dibenarkan secara syariat. Kami tidak mengetahui hal ini ada asalnya di dalam Agama Islam. Pada asalnya salat Jumat dilaksanakan satu kali di satu kota, tidak diperkenankan pelaksanaan salat jumat lebih dari satu tempat, kecuali jika ada uzur syar'i seperti jauhnya jarak tempat tinggal dari masjid atau masjid sempit sehingga tidak bisa menampung semua jemaah atau uzur lainnya yang dibolehkan untuk melakukan salat jumat di tempat lain ${ }^{24}$.

Dari serangkaian pernyataan para ulama di atas menunjukkan akan bolehnya pelaksanaan salat Jumat di berbagai tempat di sebuah kota/desa karena ada hajat seperti masjid yang sangat jauh jaraknya sehingga masyarakat sulit untuk berkumpul di satu masjid, atau hajat lainnya. Hal ini dapat dikiaskan dengan bolehnya pelaksanaan salat Jumat bagi pegawai/pekerja di tempat kerja mereka jika darurat atau ada hajat yang kuat, seperti kondisi Covid-19 sekarang ini. Meskipun hukum asalnya tidak dipersyaratkan atau diharuskan masjid sebagai tempat pelaksanaan salat Jumat. Yang diperselisihkan adalah kebolehan melaksanakan salat Jumat di beberapa tempat di satu kota atau daerah tanpa uzur yang diperbolehkan.

Jumhur ulama mengatakan bahwa tidak boleh melaksanakan salat Jumat di beberapa tempat di satu kota atau daerah tanpa uzur yang dibenarkan. Uzur yang dimaksud adalah seperti masjid berjauhan dari tempat tinggal penduduk, atau masjid kecil sehingga tidak bisa menampung seluruh jemaah, atau ada dua kelompok yang bertikai sehingga terpaksa dilaksanakan salat Jumat di dua tempat atau lebih untuk menghindari pertikaian, dan uzur lainnya. Namun jika para pegawai melaksanakan salat Jumat di masjid terdekat dari tempat kerja mereka dalam kondisi normal atau bukan dalam kondisi darurat, maka itu lebih baik dan lebih utama untuk keluar dari perbedaan pendapat para ulama.

\section{KESIMPULAN}

Penulis mengakhiri pembahasan ini dengan memberikan kesimpulan, bahwa diperbolehkan para pegawai/pekerja melaksanakan salat Jumat di selain masjid seperti di perkantoran, aula atau tempat kerja mereka jika kondisi darurat atau jika ada hajat yang

\footnotetext{
${ }^{24}$ Lihat: www.islamweb.net (diakses 15 Oktober 2020).
} 


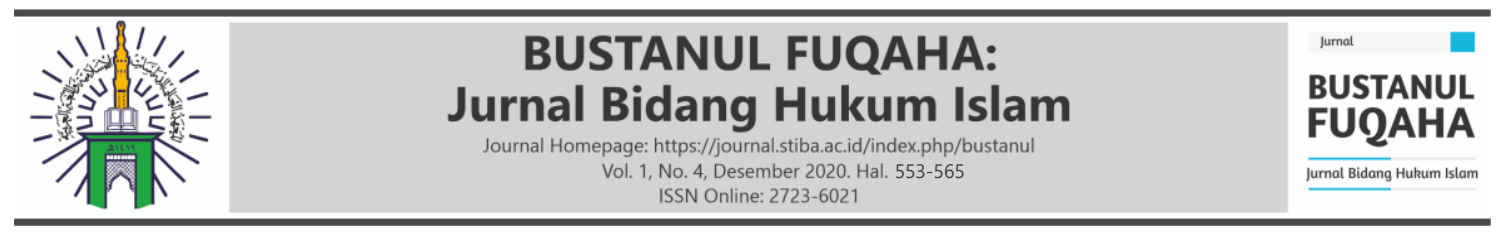

mendesak, seperti masjid terdekat dari tempat kerja tidak dapat menampung jemaah disebabkan aturan agar saf salat direnggangkan untuk menjaga jarak aman (physical distancing) di masa pandemi covid-19 ini. Namun jika masjid terdekat dapat menampung seluruh jemaah meskipun dalam posisi saf-saf salat yang renggang, maka para pegawai diharuskan untuk melaksanakan salat Jumat di masjid tersebut -berdasarkan pendapat Jumhur Ulama-, kecuali jika ada hajat seperti masjid jauh atau masjid kecil yang tidak bisa menampung banyak jemaah, atau uzur lain yang dibenarkan, maka diperbolehkan salat Jumat di tempat kerja mereka.

\section{DAFTAR PUSTAKA}

\section{Al-Quran dan Terjemahnya.}

Al-Burnū, Muhammad Șidqiy ibn Ā̄mad. (1419 H/1998). al-Wajīz fi Ị̣āh al-Qawāid alFiqhiyyah al-Kulliyyah. Cet.V; Bairut: Muassasah al-Risālah.

Al-Fauzān, Ṣālih ibn Fauzān al-Fauzān. (1423 H). al-Mulakhkas al-Fiqhiy. Cet. I; Riyad: Dār al-'Āsimah, 1423.

Al-Fauzān, 'Abdullāh ibn Ṣālih. (1424 H). Jam'u al-Maḥ̣ūl fi Syarhi Risālah ibn Sa'diy fi al-Usūul . Cet. I; Riyad: Dar al-Muslim.

Al-Jibrin, 'Abdullāh ibn 'Abd al-Raḥmān. (1422 H). Ibhāj al-Mu'minin bi Syarhi Manhaj al-Sālikìn wa Tauḍih al-Fiqhi fi al-Dīn. Cet. I; Riyad: Dār al-Watan.

Al-Maqdisy, Muaffaquddin 'Abdullāh ibn Aḥmad ibn Qudāmah. (1388 H). al-Mugniy, Vol. II. t.c; Mesir: Maktabah Qāhirah.

Al-Naisaburiy, Muhammad ibn 'Abdillah al-Hākim al-Naisabūriy. (1411 H). alMustadarak 'alā Şahīhain. Vol. II. Bairut: Dār al-Kutub al-'Ilmiyyah.

Fathur Rahim, Muh. Hamdan. (2019). Persepsi Tokoh Agama Tentang Shalat Jumat Di Dua Masjid Yang Berdekatan (Studi Kasus Desa Gilang Kec.Ngunut Kab.Tulungagung), Skripsi. Tulungagung: Jurusan Hukum Keluarga Islam, IAIN Tulungagung.

Ibn Hanbal, al-Imām Aḥmad. (1421 H). Musnad al-Imām Aḥmad ibn Hanbal. Vol. XXXVI. Cet. I; t.t: Muassasah al-Risālah.

Ibn Bāz, 'Abd al-'Azīz ibn 'Abdullāh. (1421 H). Majmū' Fatāwā wa Maqālāt Mutanawwi’ah. Cet. II; Riyāḍ: Dār al-Iṣ̣āā.

Idris, M. N., \& Anita, K. (2020). Analisis Implementasi Kaidah Fikih Lā Darar Wa Lā Dirār dalam Kedokteran Modern pada Kasus Tindakan Operasi. NUKHBATUL'ULUM: Jurnal Bidang Kajian Islam, 6(1), 50-76.

Mahmuddin, R., \& Akbar, F. (2020). Hukum Pelaksanaan Salat Jumat Dua Gelombang pada Satu Masjid di Masa Pandemi Covid-19. BUSTANUL FUQAHA: Jurnal Bidang Hukum Islam, 1(3), 350-365. 


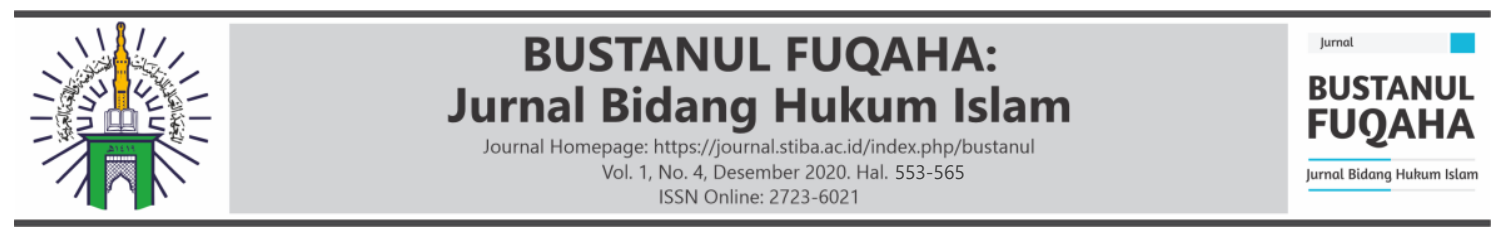

Hasibuan, E. M., \& Yusram, M. (2020). Hukum Salat Berjemaah di Masjid dengan Saf Terpisah Karena Wabah. BUSTANUL FUQAHA: Jurnal Bidang Hukum Islam, 1(2), 106-124.

Muḥammad ibn Ismā'ìl al-Bukhāriy. (1422 H). Sahīh al-Bukhāriy, Vol. I. Dar Tuq alNajah.

Muslim ibn al-Hajjāj al-Naisābūriy. (t.th) Şahīh Muslim, Vol. IV. Bairut: Dār Ihyā alTuras al-'Arabiy.

Rafi, I. (2018). Golongan yang Mendapatkan Rukhṣah dalam Ibadah Puasa dan Konsekuensi Hukumnya. NUKHBATUL'ULUM: Jurnal Bidang Kajian Islam, 4(2), 204-219.

Syatar, Abdul, dkk, (2020). "Darurat Moderasi Beragama di Tengah Pandemi Virus Corona 2019 (Covid-19)". Kuriositas: Media Sosial dan Keagamaan. Vol. 13 No.1.

Usman, M. H., Aswar, A., \& Irawan, A. W. (2020). Syariat Islam dan Kemaslahatan Manusia di Era New Normal pada Kegiataan Keagamaan dan Pendidikan. FENOMENA, 12(1), 89-106.

\section{Sumber Internet:}

$W W W . i s l a m w e b . n e t$

WWW.islamqa.info

WWW.islamway.net

WWW.islamonline.net

WWW.almoslim.net 